3. ACC/AHA Guidelines for the Management of Patients With Valvular Heart Disease. JACC 1998;32:1486-588.

4. Badhwar V, Bowling SF. Mitral valve surgery in the patiens with left ventricular dysfunction. Sem Thorac Cardiovasc Surg 2002;14:133-6.

5. Haan CK, Cabral CI, Conetta DA, Coombs LP, Edwards FH. Selecting patiens with mitral regurgitation and left ventricular dysfunction for isolated mitral valve surgery. Ann Thorac Surg 2004;78:720-5

6. Kohli V, Wasir H, Mittal S, Karlekar A, Mehta Y, Trehan N. Mitral valve repair for ischemic regurgitation in dilated cardiomyopathy. Asian Cardiovasc Thorac Ann 2005;13: 267-70.

7. Kouris N, Ikonomidis I, Kontogianni D, Smith P, Nihoyannopoulos P. Mitral valve repair versus replacement for isolated non-ischemic mitral regurgitation in patiens with preoperative left ventricular dysfunction. A longterm follow-up echocardiography study. Eur J Echocardiogr 2005;6:435-42.

8. Veselka J, Honěk T, Špatenka, a spol. Získané chlopenní vady srdce. Medcor Eur Publishing, 2000.
9. Northrup III WF. Mitral valve repair: We must do a Berger job. Current Cardiology Reports 2005;7:94-100.

10. Mehra MR, Griffith BP. Is mitral regurgitation a viable treatment target in heart failure? JACC 2005;45:388-90.

11. Akar AR, Doukas G, Szafranek A, et al. Mitral valve repair and revascularization for ischemic mitral regurgitation: predictors of operative mortality and survival. J Heart Valve Disease 2002;11:793-801.

12. Tahta SA, Oury JH, Maxwell JM, Hiro SP, Duran CMG. Outcome after mitral valve repair for functional ischemic mitral regurgitation. J Heart Valve Dis 2002;11:11-9.

13. Zipes DP, Libby P, Bonow RO, Braunwald E. Braunwald's Heart Disease. 7th ed. Philadelphia: Elsevier Saunders, 2005.

14. Aschermann M, Widimský P, Veselka J, a spol. Kardiologie. Praha: Galén, 2004.

15. Herman HC. Intervention Cardiology. Totowa, NJ: Humana Press, 2005.

Došlo do redakce 5. 6. 2006

Přijato k otištění 20. 6. 2006

\title{
Operace mitrální chlopně u pacientů s těžkou dysfunkcí levé komory - KOMENTÁŘ
}

\author{
Jiří Krupička \\ Kardiochirurgické oddělení, Nemocnice Na Homolce, Praha, Česká republika
}

Kdy ještě operovat a kdy již ne? Kam až můžeme $\mathrm{v}$ indikaci $\mathrm{k}$ operaci zajít? Existuje nějaká hranice? Pokud ano, kde je? Mưžeme jí definovat, aby naše rozhodování bylo jednodušší a abychom podle nějakého čísla nebo indexu mohli volit mezi operací a konzervativním postupem? Na tyto otázky a mnoho dalších narážíme při rozhodování o dalším postupu u rizikových pacientů, at je riziko definováno jakkoliv. Třeba jako dysfunkce levé komory srdeční u pacientů s mitrální insuficiencí. Medicína ale není tak exaktní jako matematika, takže stěží kdy najdeme jediný rozhodující parametr. Nadále platí, že „co kus, to originál“. Ve hře není jen samotná vada, ale i další proměnné, které mohou zásadním způsobem ovlivnit prognózu pacienta. Na druhé straně máme před sebou nemocného, jehož životní prognóza je významně ovlivněna a může být velmi krátká. Pacienti s mitrální insuficiencí a dysfunkcí levé komory jsou nemocní s chronickou, zpravidla dekompenzovanou, mitrální insuficiencí. Jedná se o klinicky symptomatické resp. těžce symptomatické pacienty, nebot dysfunkce levé komory znemožňuje efektivní komorovou kontrakci. Neléčená dekompenzovaná mitrální insuficience (MI) rychle progreduje do plicního edému a kongestivního srdečního selhání.

Co takovému pacientovi můžeme nabídnout? $\mathrm{Na}$ pomyslných vahách vážíme riziko přirozeného vývoje

Adresa: MUDr. Jiří Krupička, PhD., Kardiochirurgické oddělení, Nemocnice Na Homolce, Roentgenova 2, 15030 Praha 5, Česká republika, e-mail: jikru@volny.cz choroby, riziko operačního výkonu a přínos operace. A přitom nesmíme ale zapomínat na pacienta jako člověka. Chce podstoupit rizikovou operaci a při pooperačních komplikacích (které, pokud samotnou operaci přežije, jsou časté) martyrium dlouhodobé rekonvalescence, aby nakonec pochopil, že operace zcela nesplnila jeho očekávání? Má sice odoperované srdce, ale díky přetrvávající dysfunkci levé komory je stále dušný. Ocení tedy takový pacient prodloužení života o několik měsíců? Je to složité rozhodování!

Pokud se poradíme s literárními odkazy zjistíme, že vzhledem k prognóze pacienta je funkce levé komory srdeční zásadním parametrem. Čím horší funkce, tím horší prognóza a tím horší operační výsledek. Úspěchem je byt jen zakonzervování stávajícího stavu a zabránění dalšímu zhoršování její funkce. Přesto se hranice „operovatelnosti“ těchto pacientů neustále posouvá - ty, které operujeme nyní, bychom před několika málo lety odmítli s čistým svědomím, že pro ně děláme to nejlepší.

U dysfunkce levé komory je pomyslnou hranicí ejekční frakce $30 \%$. Mưžeme ji přirovnat $\mathrm{k}$ bariéře, hrdlu láhve. Kdo ji překoná, dostává se do jiného kvalitativního rozměru. A tato hranice je i v našich myslích a zásadním zpo̊sobem negativně ovlivňuje naše rozhodování. Na rozdíl např. od aortální stenózy není mitrální insuficience „homogenní diagnózou. Rozeznáváme organickou, ischemickou a funkční mitrální insuficienci a každá $z$ nich si vyžaduje poněkud jiný přístup. Bohužel v literatuře neexistuje mnoho exaktních údajů, které by řešily pacienty podle etiologie 
mitrální insuficience při dysfunkci levé komory srdeční. Zatím je řeší jako jednu diagnózu. Blok „Pro a proti“ pracovní skupiny Chlopenní a vrozené srdeční vady $\mathrm{v}$ dospělosti na brněnském sjezdu se snažil proniknout zmíněným hrdle láhve a myslím, že se mu to podařilo. Účastníci se shodli na možnosti operovat pacienty s mitrální insuficiencí a dysfunkcí levé komory při přísném individuálním přistupu. Osobně bylo pro mě velmi potěšitelné zjistit, že sekce vzbudila zájem a že v době poměrně vypjatého „politického harašení" naši přední odborníci došli $\mathrm{k}$ určitému konsenzu, a to i přes určitou různorodost názorů. Bylo to proto, že se snažili vyřešit podstatu věci!

\section{LITERATURA}

1. Braunwald's Heart Disease. 7th ed. Philadelphia: Elsevier Saunders, 2005.

2. Delahaye JP, Gare JP, Viguier E, et al. Natural histo- ry of severe mitral regurgitation. Eur Heart J 1991;12 (Suppl B):5-9.

3. Grigioni F, Enriquez-Sarano M, Ling LH, et al. Sudden death in mitral regurgitation due to flail leaflet. J Am Coll Cardiol 1999;34:2078-85.

4. Bonow RO, Carabello B, de Leon AC Jr, et al. American College of Cardiology/American Heart Association guidelines for the management of patients with valvular heart disease. J Am Coll Cardiol 1998;32:1486-582.

5. Carabello BA, Crawford FA. Valvular heart disease. New Engl J Med 1997;337:32-41.

6. Adams DH, Filsoufi F, Aklog L. Surgical treatment of the ischaemic mitral valve. J Heart Valve Dis 2002;11 (Suppl 1):S21-S25.

7. Talwalkar NG, Earle NR, Earle EA, et al. Mitral valve repair in patients with low left ventricular ejection fractions early and late results. Chest 2004;126:709-15.

8. Komárek S. Pitevní praktikum pro pokročilé. Praha: Petrov, 2000.

Došlo do redakce 12. 6. 2006

Přijato k otištěni 20. 6. 2006 